\title{
Organizational and methodological approach to managing financial flows of agricultural enterprises
}

\author{
Alsou Zakirova, ${ }^{1,}$, Guzaliya Klychova ${ }^{1}$, Gamlet Ostaev $^{2}$, Evgenia Zaugarova ${ }^{3}$, Almaz \\ Nigmetzyanov", and Elena Zaharova ${ }^{2}$ \\ ${ }^{1}$ Kazan State Agrarian University, Karl Marx, 65, Kazan, 420015, Russia \\ ${ }^{2}$ Izhevsk State Agricultural Academy, Studencheskaya, 11, Izhevsk, 426069, Russia \\ ${ }^{3}$ Saint-Petersburg State Economic University, Sadovaya, 21, St. Petersburg, 191023, Russia \\ ${ }^{4}$ Kazan branch of the Russian State University of Justice, 2nd Azinskaya street, 7A, Kazan, 420088, \\ Russia
}

\begin{abstract}
Management accounting and management of an agricultural enterprise includes strategic planning and regulation of financial flows. Therefore, at the present stage, the development of measures to develop management accounting and improve the management of financial flows of agricultural enterprises is a significant problem. Management accounting and management of financial flows is the management of cash (financial) flows arising in the process of promotion of tangible and intangible assets. Besides, in the process of management accounting there is a purposeful distribution of financial resources in the logistic financial system of an agricultural enterprise. Management of financial flows is carried out both for the internal environment of the agricultural enterprise and for the external environment. The aim of the article is the justification of theoretical provisions and development of organizational and methodical approach to management of financial flows of agricultural enterprises in the system of management accounting. Objectives of the research: to determine the main components, directions and mechanism of development in the management accounting of financial strategy; to develop a method of management accounting for management of financial flows of developing enterprises, planning to expand their activities in the long term.
\end{abstract}

\section{Introduction}

The economic efficiency of any enterprise, including enterprises of the agricultural sector, is based on an organized management accounting, an effective developed market (agrarian) strategy, perfect and efficient use of monetary and other resources, minimizing a number of risks [1, 2]. Management accounting is designed to solve all these problems without exception. Besides, management accounting of financial flows is a procedure of research

${ }^{*}$ Corresponding author: zakirovaar@mail.ru 
and adoption of administrative conclusions and decisions associated with the emergence and distribution of financial (economic) flows of an agrarian enterprise $[3,4,5]$.

The purpose and task of management accounting of financial (economic) flows is to provide timely financial (economic) resources for financial and economic activities of an agrarian enterprise provided that the conditions of their balance, financial (economic) stability, solvency and liquidity for the reporting and planned periods are observed $[6,7]$.

By sustainable development of agricultural business we understand the process of irreversible natural change in the interrelated economic, environmental and social components of the enterprise, caused by external and internal factors, aimed at achieving a new sustainable state $[8,9]$. This is a process that is constantly independent of business. At the same time, the sustainable development of agricultural business is strategic, because in the process of its implementation the medium and long-term goals of activities are achieved $[10,11]$. The direction of management accounting development reflects the strategy, including financial.

Financial strategy is one of the most important types of functional strategy, which provides all the main directions of development of financial activity of an enterprise, as well as development of financial relations by forming long-term financial goals, choosing the most effective ways of their achievement, adequate correction of directions of formation and use of financial resources in case of changes in the environment $[12,13]$.

This definition of the financial strategy is aimed at development of agricultural business in the long-term perspective in the modern conditions taking into account the variability of the external environment.

\section{Materials and Methods}

The financial strategy, developed for the purposes of management of management accounting specialists, should cover all stages of agricultural business development, regardless of the type of activity and branch belonging, taking into account climatic conditions and state policy in the field of agriculture. Management accounting has all the tools and mechanisms to meet the information needs of users at all levels of management for management decision-making, including the development of financial strategy $[14,15]$.

The importance of developing management accounting for financial strategy in an enterprise is that finance is the source for the development of other strategies. Thus, financial resources are one of the main limitations of the volume and directions of enterprise activities.

The relevance of development in management accounting of financial strategy for any agricultural business is determined:

- the intensity of changes in the external financial environment factors. Frequent fluctuations of the financial market conditions, instability of the state economic policy and forms of regulation of financial activity, as well as the main macroeconomic indicators of the financial activity of enterprises and their high dynamics do not allow to effectively manage the finances of the enterprise on the basis of the accumulated experience. Therefore, the absence of a developed financial strategy may lead to contradictions and decrease in efficiency of financial activity in general;

- the upcoming transition to a new stage in the life cycle. At each stage of the enterprise typical level of investment activity, directions and forms of financial activity, and also features of formation and distribution of the finance are peculiar to it. The developed financial strategy allows to adapt financial activity in advance to the forthcoming changes of possibilities of economic development of the enterprise;

- cardinal changes in the objectives of the operational activity of the enterprise. It is connected with new commercial opportunities. In the implementation of such objectives, 
the enterprise needs to change the production range, introduce new production technologies, as well as develop new markets, etc.. [16]. Under these conditions, a significant increase in the investment activity of the enterprise and diversification of the forms of its financial activity should be of a predictive nature, provided by the development of a clearly formulated financial strategy.

An important role in ensuring effective development of an enterprise is played by the development of management accounting of financial strategy by specialists (Figure 1).

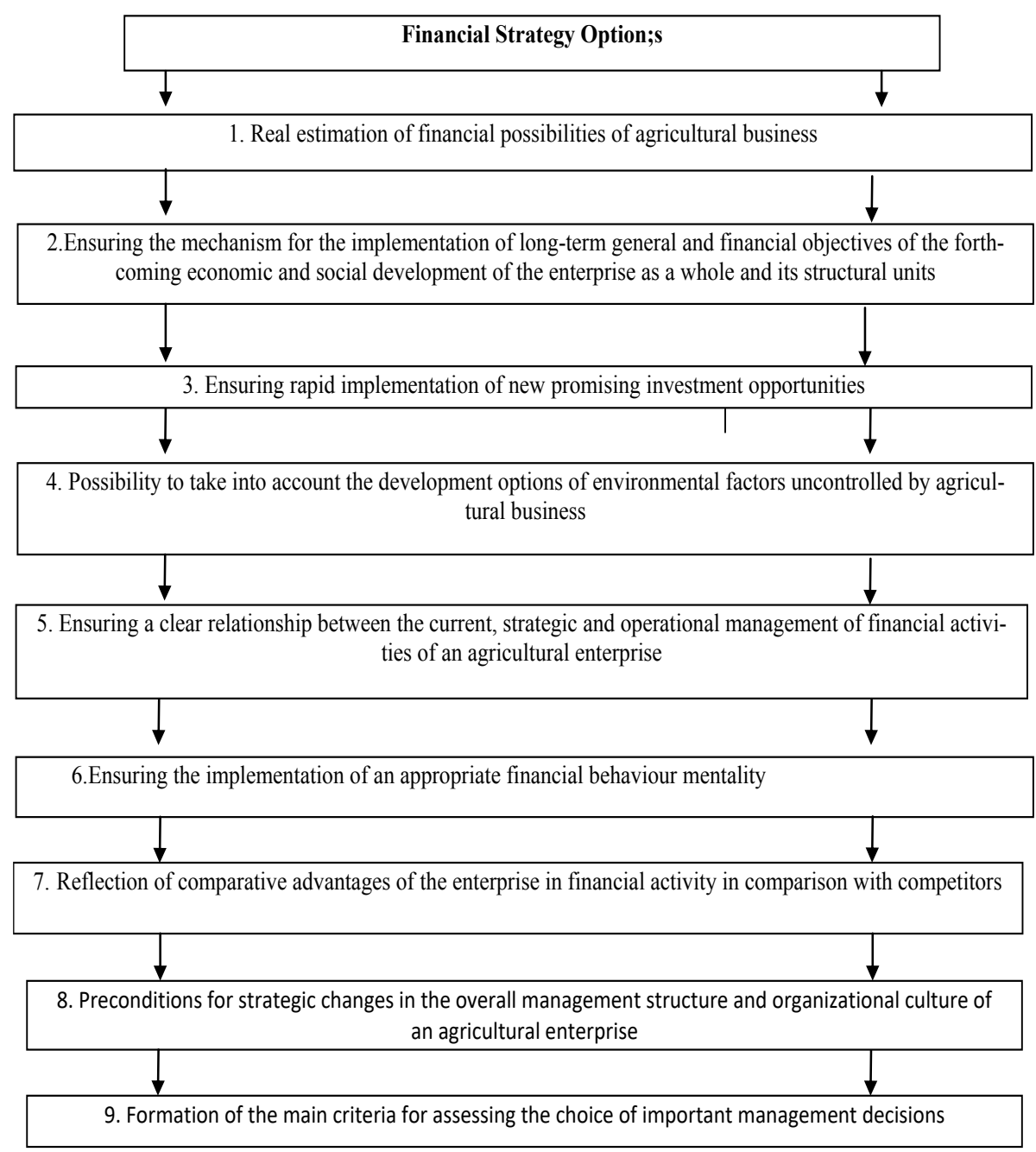

Fig. 1. Financial strategy and its capabilities

The main purpose of strategic management accounting, including in the field of financial activity, is to maximize the market value of the business, which allows the agricultural enterprise to develop its potential and maintain its strategic ability to survive and function effectively in an unstable environment.

Figure 2 shows a detailed scheme of financial strategy, characterizing the full range of its elements. 


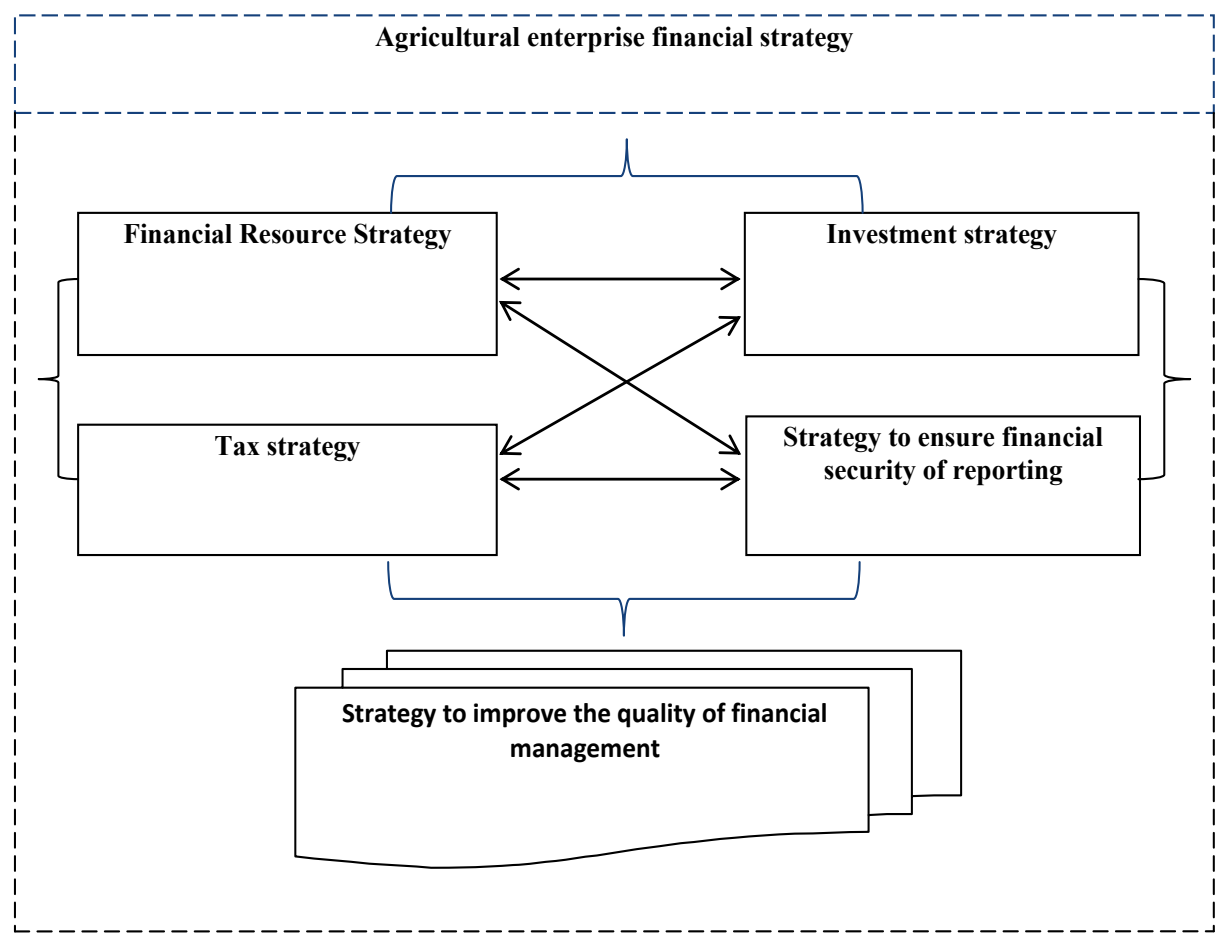

Fig. 2. Main components of the financial strategy of an agricultural enterprise (business entity)

Decision making under any of these components requires an assessment of the impact of these decisions on changes in the development parameters of other components of the financial strategy of the business. Achieving the goal of any module of the developed model in management accounting of financial strategy requires assessment of decisions, but at the same time has its own goals and objectives:

1. The strategy of building financial resources - building the capacity of financial resources of the enterprise (sufficient to meet the needs of its development) [17].

The system of main problems to be solved includes achieving a stable increase in the volume of own sources of financing; attracting the necessary external financing with minimum costs; optimizing the structure of sources of financial resources and providing financial flexibility.

2. Investment strategy - rational use of financial resources of an enterprise (correct distribution of financial resources depending on the directions and forms of investment, taking into account the criterion of risk/return ratio) [18, 19, 21].

3. The strategy of ensuring the financial security of the company - provides financial stability of the company in the process of strategic development. The main significant tasks of ensuring financial stability consist in identification and assessment of financial risks and development of a set of measures for their management; ensuring stable solvency and financial stability, implementation of solutions in the field of anti-crisis management (both in terms of preventive measures and actions in case of signs of crisis).

4. Strategy to improve the quality of management of the company's financial activities in the strategic perspective - creation of an effective financial structure (ensuring a high level of qualification and organizational culture of financial managers, formation of the necessary information base that allows modeling financial performance in relation to future periods) [22]. 
5. Tax strategy - optimization of the tax burden (ensuring the growth of undistributed profits of the enterprise in conditions of an acceptable level of tax risks).

Taking into account the specifics of agricultural business, the financial strategy should be linked to the life cycle of the enterprise. Since an enterprise goes through a number of stages in its development, financial development in management accounting can be represented in the form of the following stages: formation, growth, maturity, decline. At the same time, it is obvious that financial strategy in management accounting should be determined on the basis of what stage of financial development it is at.

Since the financial strategy in management accounting covers a rather long interval, it becomes objective to determine the current stage of financial development, as well as the possibilities and conditions of transition to a new stage.

In order to define strategic financial goals in management accounting for further development of a business entity, the financial strategy matrix is applied. Franchon and I. Romanet.

It should be noted that agricultural enterprises are significantly different from industrial and processing companies in that they depend largely on natural factors and are more risky, Therefore, subsidies and subsidies provided by the State play a major role in the activities of an agricultural enterprise. Therefore, they should be taken into account when determining the results of economic activity.

The assessment of the enterprise's position is based on the calculation of three indicators (Table 1).

Table 1. Evaluation of the situation of an agricultural business entity

\begin{tabular}{|c|c|c|c|}
\hline $\begin{array}{l}\text { No, } \\
\text { p/p }\end{array}$ & Indicator & Formula & Formula indicators \\
\hline 1 & $\begin{array}{l}\text { Results of } \\
\text { business } \\
\text { activity of a } \\
\text { business } \\
\text { entity (RCD) }\end{array}$ & $\begin{array}{c}\mathrm{RHD}=\mathrm{Qr}-\mathrm{S}- \\
\mathrm{ZP}-\mathrm{Z}-\mathrm{KrZ} \\
+\mathrm{DZ}-\mathrm{PI}+\mathrm{OPI} \\
+\mathrm{SID}\end{array}$ & $\begin{array}{l}\text { Qr - revenue from the sale of products of the business } \\
\text { entity; } \\
\text { S - the cost of production of the subject of business; } \\
\text { ZP - the cost of labor of the subject of the business; } \\
\text { KrZ - accounts payable of the subject of the business; } \\
\text { Dz - accounts receivable of the business entity; } \\
\text { OPI - ordinary sale of business entity's property; } \\
\text { SID - subsidies and subsidies of a business entity. }\end{array}$ \\
\hline 2 & $\begin{array}{l}\text { Financial } \\
\text { result of the } \\
\text { business } \\
\text { entity (RFD) }\end{array}$ & $\begin{array}{c}\mathrm{RFD}=\Delta \mathrm{ZS}- \\
\mathrm{FZ}-\mathrm{NPR}-(\mathrm{D}+ \\
\mathrm{DDFD})\end{array}$ & $\begin{array}{c}\Delta Z \mathrm{Z} \text { - change in borrowings of a business entity; } \\
\text { FZ - financial expenses on borrowed funds of a } \\
\text { business entity; } \\
\text { NPR - profit tax of a business entity; } \\
\text { D - dividends of the subject of business; } \\
\text { DDFD - other income from financial activities of a } \\
\text { business entity. }\end{array}$ \\
\hline 3 & $\begin{array}{l}\text { The result of } \\
\text { financial and } \\
\text { economic } \\
\text { activity of } \\
\text { the business } \\
\text { entity. } \\
\text { (RFHD) } \\
\end{array}$ & $\begin{array}{c}\text { RFHD }=\text { RHD + } \\
\text { RFD }\end{array}$ & $\begin{array}{c}\text { RHD is a result of the economic activity of a business } \\
\text { entity. } \\
\text { RFD - result of financial activity of a business entity }\end{array}$ \\
\hline
\end{tabular}

For a business entity, it is desirable that the result of financial and economic activity be positive. The dynamics of the result of economic activity fits into the life cycle of the subject of business: the period of positive result of financial and economic activity is replaced by negative and so on, provided that the subject of business normally develops.

Having calculated the main indicators indicated above, a business entity can be attributed to one of the quadrants of the matrix (each of which has its number and name, as 
well as recommendations and the possibility of transition to other quadrants), and to determine at what stage of financial development is the business entity (Table 2).

Table 2. Matrix for determining the stage of financial development according to the methodology of J. Franchon and I. Romanet (adapted for agricultural business) (above diagonal AB - zone of success - zone of positive values of analytical indicators, under diagonal - zone of negative values of analytical indicators)

\begin{tabular}{|c|c|c|c|}
\hline $\begin{array}{l}\text { Stages of financial } \\
\text { development }\end{array}$ & Decline & Maturity & Growth \\
\hline & $\mathrm{RFD}<0$ & $\mathrm{RFD}=0$ & RFD $>0$ \\
\hline RHD $>0$ & $\begin{array}{l}\text { 1 " Father of the family" } \\
\text { (Cancellation of attracted } \\
\text { funds of a business entity) } \\
\text { RFHD =0 }\end{array}$ & $\begin{array}{c}4 \text { "Rantier" } \\
\text { (Shortage of working capital } \\
\text { of the business entity) } \\
\text { RFHD }>0\end{array}$ & $\begin{array}{l}\text { 6"Maternity Society" } \\
\text { (Deficit of liquid funds } \\
\text { of the business enti- } \\
\text { ty)RFHD }>0\end{array}$ \\
\hline $\mathrm{RHD}=0$ & $\begin{array}{c}7 \text { "Episodic deficit." } \\
\text { RFHD }<0\end{array}$ & $\begin{array}{c}2 \text { "Sustainable Balance" } \\
\text { RFHD }=0\end{array}$ & $\begin{array}{c}5 \text { "Attack" } \\
\text { (liquidity surplus) } \\
\text { RFHD }>0\end{array}$ \\
\hline RHD $<0$ & $\begin{array}{c}9 \text { " Crisis " } \\
\text { RFHD }<0\end{array}$ & $\begin{array}{c}8 \text { "The Dilemma" } \\
\text { (clear liquidity surplus) } \\
\text { RFHD }<0\end{array}$ & $\begin{array}{c}\text { 3"Unstabła balance." } \\
\text { RFHD }^{=} Q\end{array}$ \\
\hline
\end{tabular}

At the same time, quadrants 4, 6, 5 directly reflect the creation of liquid assets of an agricultural enterprise, namely, there is an excess of current assets. In quadrants 7, 8, 9 related to the consumption of liquid assets of an agricultural enterprise we can say that they reflect the current assets deficit.

Horizontally, the result of financial and economic activities is directly related to the growth of borrowings from agricultural enterprises. At that, we proceed from the negative value of the result of financial and economic activity to the positive value. Vertically, the result of financial and economic activities is directly related to the growth of borrowings of funds of an agricultural enterprise. This activity is related to the implementation of an investment project (mass investment of funds). Accordingly, this can explain the transition from a positive result of financial and economic activity (a great opportunity to start implementing an investment project) to a negative result of financial and economic activity (the situation of a significant investment of funds).

Thus, the use of this matrix in management accounting will allow the management of the business entity to make decisions on the integrated use of all financial resources aimed at achieving the goals of the financial strategy. 
Having defined the development quadrant and the stage of its life cycle, agricultural business entities should build their financial strategy taking into account the policies of local governments and the Ministry of Agriculture.

\section{Results}

The main sources of management accounting information on financial flows of an agricultural enterprise are: accounting (financial) statements, financial documents (primarily financial plans) and management accounting data.

Data on financial resources and financial flows of the enterprise, which can be obtained from the financial statements, are presented in Table 3.

Table3. Data obtained from the accounting statements for the purpose of managing the financial flows of the enterprise.

\begin{tabular}{|c|c|c|}
\hline $\begin{array}{c}\text { No } \\
\text { p/p }\end{array}$ & Data on financial resources and financial flows & Reporting Form \\
\hline 1 & $\begin{array}{c}\text { Information on availability, total value and } \\
\text { structure of financial resources }\end{array}$ & Balance sheet \\
\hline 2 & $\begin{array}{c}\text { Information on financial resources movement } \\
\text { during the quarter (half-year, nine months and } \\
\text { reporting year) }\end{array}$ & Balance sheet \\
\hline 3 & Information for estimating financial flows & $\begin{array}{c}\text { Balance sheet, Statement of Financial } \\
\text { Performance, Capital Flow Statement, } \\
\text { Cash Flow Statement }\end{array}$ \\
\hline 4 & $\begin{array}{c}\text { Information for assessment of liquidity, solvency, } \\
\text { financial stability, return on invested capital }\end{array}$ & $\begin{array}{c}\text { Balance sheet, Statement of Financial } \\
\text { Performance }\end{array}$ \\
\hline 5 & $\begin{array}{c}\text { Information to assess the sources of financial } \\
\text { resources and the ability of the enterprise to self- } \\
\text { financing, in particular: } \\
\text { - increase of financial resources at the expense of } \\
\text { internal and external sources, etc. }\end{array}$ & $\begin{array}{c}\text { Capital Flow Statement, Cash Flow } \\
\text { Statement }\end{array}$ \\
\hline 6 & $\begin{array}{c}\text { Cash flows for the period } \\
\text { - deficit/overage of financial resources }\end{array}$ & $\begin{array}{c}\text { Balance sheet, Statement of Financial } \\
\text { Performance, Cash Flow Statement }\end{array}$ \\
\hline
\end{tabular}

At the same time, if only accounting (financial) statements are available, it is impossible to make full conclusions about the status and management of financial flows at an agricultural enterprise, it is not enough for the current management of financial flows. For management accounting and management of financial flows, information on dynamics and directions of their change is necessary.

In the course of their activities, agricultural enterprises analyze various financial indicators.

The dynamics of the obtained financial indicators, certainly, allows estimating the current state, making conclusions about the weaknesses and strengths of the object under study, but does not fully meet the requirements of effective management of financial flows of such enterprises. Since it is not enough to analyze (disassemble) already accomplished actions (facts of economic activity of an agrarian enterprise), it is necessary to carry out strategic planning for the future, calculating the result (outcome) and the impact that they can have on the financial (economic) position of the enterprise after the changes have been made.

The main purpose of management planning is to optimize the activities of an agricultural enterprise, namely, to create maximum measures that characterize the order of 
completion of certain goals, taking into account the probabilities (abilities) and opportunities for more efficient use of resources of the entire enterprise as a whole.

Management planning of financial flows will allow to reveal conformity between available financial (economic) resources of agrarian enterprise and necessity (need) in them, to carry out a choice of effective sources of formation (attraction) of financial resources and paid off variants of their use (investment). Traditionally introduced at agrarian enterprises systems (concepts) of financial flows management include appropriate blocks: purpose, principles and objectives of management, management mechanism, organizational support, information support, control over execution of the plan (forecast) on financial flows (Figure 3).

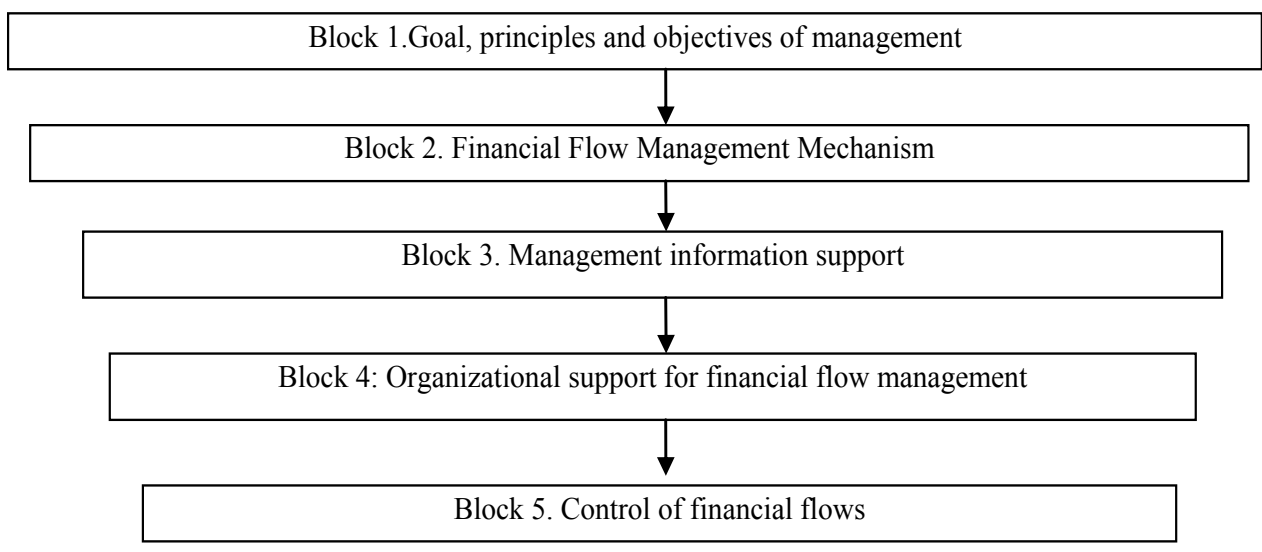

Fig. 3. Ecological and economic result of reclamation works.

Block 1: Management purpose, principles and objectives.

The main purpose of financial flow management is to ensure uninterrupted existence of the enterprise in the current and future periods.

Block 2: Mechanism for managing financial flows. This mechanism consists of the following elements:

- government regulation;

- market-based regulatory mechanism;

- internal regulatory mechanism established within the enterprise by its internal documents;

- system of specific management methods and techniques: financial accounting, financial analysis, financial planning and financial control.

Block 3: Information support for management, which is a set of data on actual and possible state of financial flows.

Block 4 Organizational support of financial flow management implies the presence in the enterprise of internal structural subdivisions, performing certain works on development and research, as well as implementation of management decisions and conclusions according to the problems of financial (economic) flow management and responsible for these decisions and decisions.

Block 5. Control of financial flows. Supervision over execution of the plan (project) on financial flows includes the procedure of control over ensuring execution of management decisions in the field of their development and application.

In our opinion, the system of regulation and management of financial flows, in addition to the above blocks, should also include the following components: methods (methods and procedures) of raising finance and ways of investing (investing) funds. 
To this end, we offer a management accounting methodology to manage financial flows of developing enterprises planning to expand their operations in the long term. This methodology has two main directions: attraction of funds and use of funds (Figure 4).

Development of the financing strategy includes: assessment of the need to attract financing, selection of optimal sources of financing and investment of funds, preparation of necessary documents for investors.

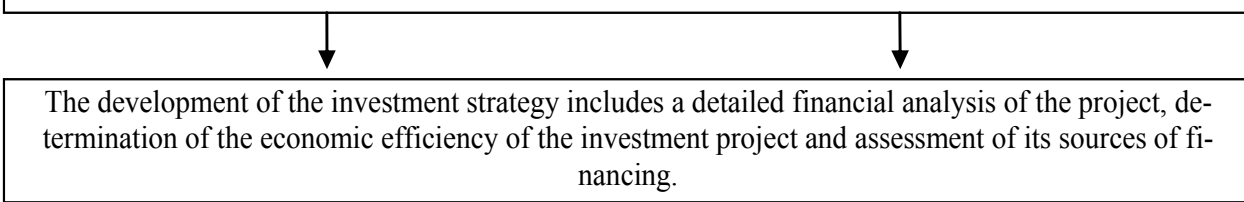

Fig. 4. Main directions of attraction and use of monetary funds.

Once the need for additional funding has been identified, it is necessary to determine from which sources the need can be met and where available free financial resources can be directed.

The management accounting methodology that we are developing should meet the following requirements:

- must contain a sequence of specific transactions, which are acceptable in practice and which would yield positive financial results;

- must characterize in general, at the system level and the level of actions, the step-bystep know-how of the technology of decision making and opinions on management of financing and investment attraction.

The purpose of the proposed method of management accounting is to process and further group existing methods of attracting financing depending on the type of economic operation and identify the main ways to invest (invest) temporarily free cash assets of an agricultural enterprise in the long term and based on this development of management decisions for a particular enterprise.

In our opinion, the method of management accounting for attracting financing should include the blocks presented in Table 4.

Table 4: Methodology of management accounting for fundraising

\begin{tabular}{|c|c|c|c|c|c|c|c|}
\hline № & \multicolumn{7}{|c|}{ Attracting, directing and evaluating funding } \\
\hline 1 & \multicolumn{7}{|c|}{ Raising financing. } \\
\hline \multicolumn{4}{|c|}{ Identification of funding requirement } & \multicolumn{4}{|c|}{$\begin{array}{l}\text { Determining the use of attracted funds (debt servicing, } \\
\text { project implementation, current activities, etc.). }\end{array}$} \\
\hline 2 & \multicolumn{7}{|c|}{$\begin{array}{c}\text { Areas of use } \\
\text { (largely determine the source of funding, as each source imposes its own limitations on the } \\
\text { directions of use) }\end{array}$} \\
\hline \multicolumn{2}{|c|}{$\begin{array}{l}\text { Source of financing } \\
\text { selection }\end{array}$} & \multicolumn{3}{|c|}{$\begin{array}{l}\text { Implementation of } \\
\text { measures to attract } \\
\quad \text { financing }\end{array}$} & \multicolumn{2}{|c|}{$\begin{array}{c}\text { Estimation of source } \\
\text { influence on balance } \\
\text { sheet structure }\end{array}$} & $\begin{array}{l}\text { Evaluation of the } \\
\text { overall project } \\
\text { effectiveness (cost of } \\
\text { engagement) }\end{array}$ \\
\hline 3 & \multicolumn{7}{|c|}{$\begin{array}{c}\text { Project Performance Evaluation } \\
\text { (once funding is secured, it will be analyzed) }\end{array}$} \\
\hline \multicolumn{3}{|c|}{ Analysis of cash flow } & \multicolumn{3}{|c|}{ Financial coefficient Analysis } & \multicolumn{2}{|c|}{$\begin{array}{l}\text { Financial stability, solvency } \\
\text { and liquidity analysis }\end{array}$} \\
\hline
\end{tabular}

In turn, the management accounting methodology for the use (investment) of funds should include the following steps presented in Table 5. 
Table 5: Management accounting methodology for the use of financing

\begin{tabular}{|c|c|c|c|c|}
\hline No & \multicolumn{4}{|c|}{ Use and evaluation of financing. } \\
\hline 1 & \multicolumn{4}{|c|}{ Use of investments } \\
\hline \multicolumn{2}{|c|}{$\begin{array}{l}\text { Determination based on the } \\
\text { analysis of the availability of } \\
\text { temporarily free cash assets }\end{array}$} & $\begin{array}{l}\text { Choice of } \\
\text { investment } \\
\text { direction }\end{array}$ & $\begin{array}{l}\text { Investment } \\
\text { project } \\
\text { development }\end{array}$ & $\begin{array}{l}\text { Assessment of the } \\
\text { effectiveness of the } \\
\text { investment project }\end{array}$ \\
\hline 2 & \multicolumn{4}{|c|}{$\begin{array}{c}\text { Evaluation of the efficiency of the investment project (to be carried out by } \\
\text { calculation) }\end{array}$} \\
\hline \multicolumn{2}{|c|}{$\begin{array}{l}\text { Calculation of return on } \\
\text { investment }\end{array}$} & \multicolumn{2}{|c|}{$\begin{array}{c}\text { Calculation of the payback } \\
\text { period of investments }\end{array}$} & $\begin{array}{l}\text { Calculation of the coefficient of } \\
\text { investment efficiency }\end{array}$ \\
\hline
\end{tabular}

Profitability of investments shows the ratio of all received profit for the period of validity of the project to the amount of investments invested in it.

The term of return on investment characterizes time from the beginning of realization of the investment project to the moment when the given investment investments are covered by total results from realization of this project $(\mathrm{PP}=\min \mathrm{t})$. This indicator is measured in months and years. That is:

$$
\mathrm{PP}=\min \mathrm{t} \text {, at which } \mathrm{DP}=\mathrm{I}
$$

where the DP is the balance of accumulated cash flow from operations;

And - the size of the initial investment in the project.

It can also be calculated as:

$$
\mathrm{PI}=\mathrm{M} / \mathrm{CP}
$$

where the $\mathrm{CP}$ is an annual net profit.

The index of profitability (ID) of the investment project at the expense of own funds allows to estimate the relation of the resulted incomes to the resulted capital investments and shows relative profitability of the project in calculation on unit of investments:

$$
\mathrm{ID}=\mathrm{CDD} / \mathrm{I}
$$

where the $\mathrm{CDD}$ is a net discounted income.

The need for financing, or the availability of surplus funds is determined using the formula for calculating the current financial needs of the enterprise (TFP) and the availability of own working capital (Self):

where $\mathrm{Z}$ is the stock level;

$$
\mathrm{TFP}=\mathrm{H}+\mathrm{DZ}-\mathrm{KZ}
$$

$\mathrm{DZ}$ - the amount of receivables;

$\mathrm{KZ}$ - the amount of accounts payable

where the SK is the amount of equity;

$$
\mathrm{Sob}=\mathrm{SC}+\mathrm{DO}-\mathrm{VA}
$$

DO is the value of long-term liabilities;

VA - non-current assets.

Potential cash deficit/surplus is the difference between own working capital and current financial needs.

If Sob>TFP, the enterprise has a potential surplus of its own working capital and there is no need for short-term financing.

If Sob <TFP, then the enterprise has a shortage of funds and it needs a loan in the amount - the difference between current financial needs and own working capital

\section{Discussion}

In the conditions of modern economy for the purpose of effective management of an agricultural enterprise and its existence in conditions of severe competition, including at the international level, it is obviously necessary to integrate various elements of management 
accounting into a single system that would provide support for economically balanced management decisions, increase productivity and competitiveness. In practice, certain elements of management accounting are usually used at enterprises. It is important that these elements are combined into a common structure focused on achieving a certain result. The system of management accounting, being one of the most effective means of planning and forecasting, exercising operational control over the efficiency of the use of resources of the enterprise, increasing its investment attractiveness, is a complex, multifaceted system, characterized by unity and correlation with the external environment, structure, hierarchy, permanence in functioning and evolution, purposefulness, etc [23].

According to many experts, today the most attractive companies in the field of external investments are those that have a transparent ownership structure and an efficient, modern management system; comply with international financial and management accounting standards; operate in the market with high potential; and provide an opportunity for an investor to withdraw from investment without significant losses. In other words, we see that two of the five components of the investment attractiveness are in the field of accounting and management, therefore, the need to improve the quality of management and efficiency of business has determined the evolutionary development of management accounting, its tasks, functions and tools.

The tool of management accounting should be understood as a systematized set of accounting, analytical and control methods, used for the practical implementation of certain management decisions in order to achieve optimal results in the activities of individual business segments. The conducted researches of economists' works in the field of management accounting allowed to define the tools, which are the most essential and take into account the peculiarities of agricultural production: budgeting on the zero basis; budgeting based on actions; direct-casting; standard cost; $\mathrm{ABC}$ method; normative method of accounting; CVP-analysis; STEP- and SWOT-analysis; system of management reports; internal control system; accounting policy of management accounting, etc.

One of the management accounting tools is budgeting. The system of budgeting, using the possibilities of modern information technologies, provides an opportunity for internal economic control and multivariate analysis of financial results from the implementation of adopted budgets, forms conditions for the analysis of various scenarios of transformation of financial condition, assessment of financial stability in permanently changing conditions of external economic environment $[24,25]$. In budgeting, budgets for the forthcoming period are prepared, reports on their execution for the past time are prepared, and planned and actual indicators are compared. This allows to conduct the so-called analysis of deviations, i.e. to assess the level of deviations of actual indicators from the planned ones and the reasons for their occurrence [26].

CVP-analysis, STEP- and SWOT-analysis, XYZ-analysis, deviations analysis can be referred to the methods of economic and statistical analysis, which form the toolkit of management accounting.

CVP-analysis (CVP-volume-rrofit, in translation - "costs - volume - profit") is one of the effective methods of marginal analysis, distribution of resources by kinds of production and decision-making on production, rendering, performance of works.

The next method of economic and statistical analysis is STEP-analysis, which evaluates the strategic climate of the external environment, and its results include space structuring, expert assessment of external environment factors.

The STEP-analysis includes the following stages: determination of external strategic factors having a high probability of implementation and influence on the activity of the organization; assessment of the possibility of implementation of each event for a certain organization by assigning it the established weight from one (main) to zero (insignificant); assessment of the degree of influence of each event-factor on the strategy of the 
organization on a five-point scale; determination of weighted assessments by multiplying the weight of the factor (weight factor) by the force of its influence and calculation of the sum. The total score shows the extent to which the organization is ready to respond to projected and current environmental factors. We consider it reasonable to select the following factors for the STEP analysis of agricultural organizations (Table 6).

Table 6. STEP-analysis of agricultural organizations activities

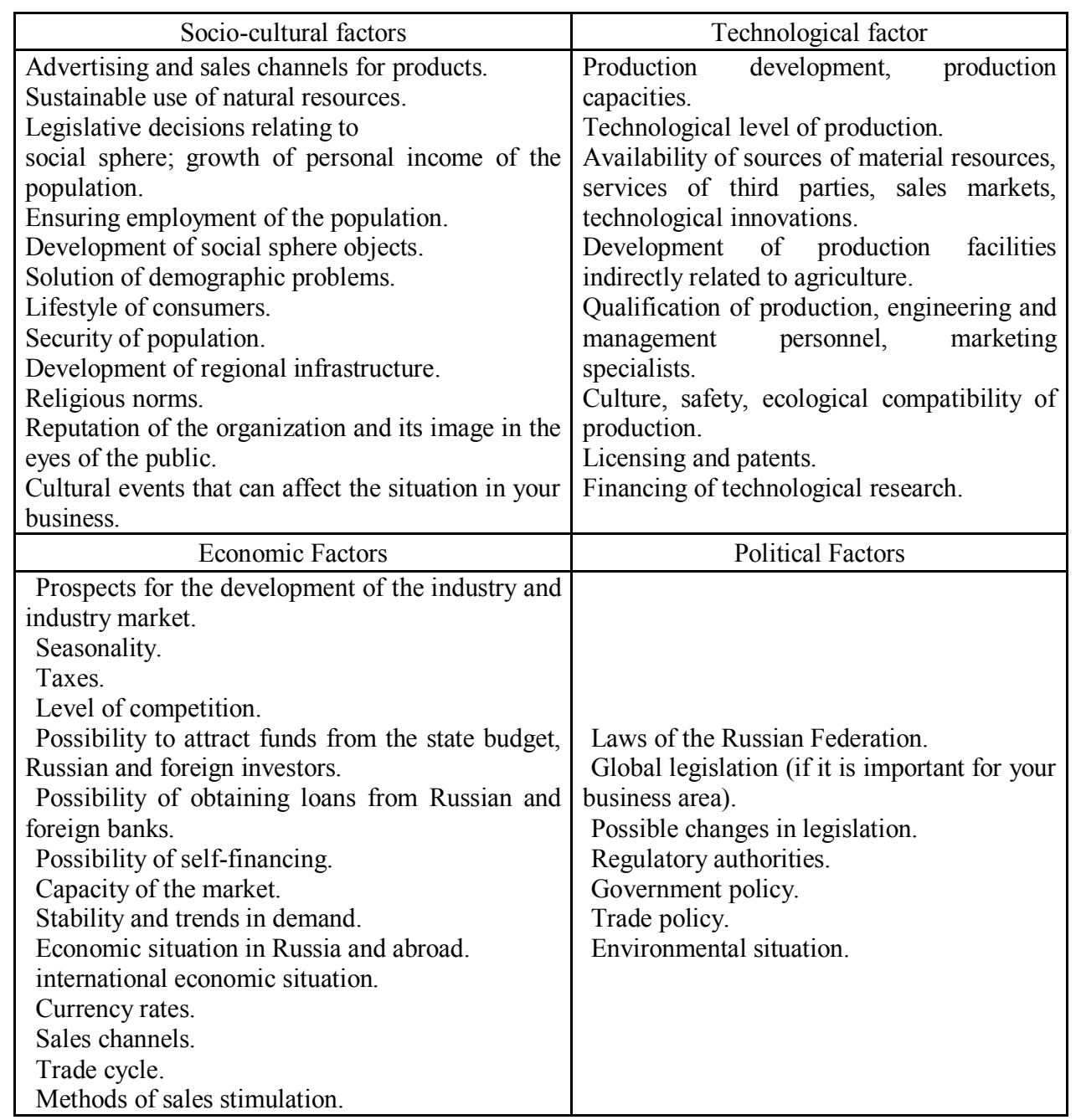

In order to get a clear assessment of the strategic position of the subject of the research and the market situation, to find out whether the external situation is sufficiently used, it is possible to apply SWOT-analysis, on the basis of which to form a promotion strategy [27. 28].

During the SWOT-analysis auxiliary tables (matrices) are used. SWOT analysis emphasizes that the strategy should combine the best possible internal capabilities (strengths and weaknesses) and external situation (reflected in opportunities and threats).

We believe that this methodology can be applied to SWOT analysis of agricultural organizations. For this purpose, it is necessary to identify factors (they should be considered in SWOT-analysis), which would take into account the specifics of agricultural production (Table 7). 
Table 7. The main factors for SWOT-analysis of activity agricultural organizations

\begin{tabular}{|c|c|}
\hline Strengths (benefits) & Opportunities \\
\hline $\begin{array}{l}\text { Stable financial position of the organization. } \\
\text { There is a large production and labor potential. } \\
\text { Management's desire to solve the existing } \\
\text { problems with new methods. } \\
\text { Total control over prices is carried out. } \\
\text { Economic Service carries out investment } \\
\text { calculations, makes business plans. } \\
\text { The modern technology of manufacture is } \\
\text { applied. } \\
\text { Well organized social infrastructure in the } \\
\text { economy. } \\
\text { The quality of goods is higher than that of } \\
\text { competitors. } \\
\text { State support. }\end{array}$ & $\begin{array}{l}\text { More efficient and rational use of production } \\
\text { resources. } \\
\text { Opportunity to enter new markets. } \\
\text { Opportunity to apply new technologies. } \\
\text { Improvement of management structure: } \\
\text { Drawing up a long-term strategic plan; } \\
\text { - Drawing up an operational plan for the } \\
\text { organization based on the strategic plan; } \\
\text { - organization of works on control over } \\
\text { financial activity of the enterprise; } \\
\text { - carrying out of certification of employees } \\
\text { of the management apparatus. } \\
\text { Introduction of tax benefits. } \\
\text { Opportunities to expand the range of goods } \\
\text { and services. } \\
\text { Favourable geographical location. } \\
\text { Possibilities of creating new production } \\
\text { facilities.. }\end{array}$ \\
\hline Weaknesses (deficiencies) & Threats \\
\hline $\begin{array}{l}\text { Lack of clearly defined higher (strategic) } \\
\text { development goals for the organization. } \\
\text { The absence of a strategic plan for the } \\
\text { development of the organization, as a result, the } \\
\text { operational plan does not have a basis for more } \\
\text { accurate calculations and is poorly focused on } \\
\text { the future development of the organization } \\
\text { In concrete calculations of loans and } \\
\text { investments. } \\
\text { Poorly organized internal control system. } \\
\text { Partially outdated equipment. } \\
\text { Poorly organized marketing activities. } \\
\text { Lack of cost management. } \\
\text { Lack of a clear financial policy. } \\
\text { Lack of specialists with efficient working } \\
\text { methods. } \\
\text { Lack of clearly organized functional structure. }\end{array}$ & $\begin{array}{l}\text { The economic crisis. } \\
\text { Outdated machinery and equipment. } \\
\text { A constantly changing tax policy. } \\
\text { Shortage of highly qualified workers. } \\
\text { Disparity of prices. } \\
\text { Seasonal fluctuations. } \\
\text { Growing competition. } \\
\text { Influence of natural factors. }\end{array}$ \\
\hline
\end{tabular}

On the basis of a comprehensive analysis of tools we consider it necessary to develop an information map of the methodological support of management accounting of an agricultural organization, allowing to determine the impact of management accounting tools on management decision making by individual segments of activity.

\section{Conclusions}

Thus, management and organization of financial flows using management accounting tools is one of the most important elements of financial policy of modern agricultural enterprises. The quality and efficiency of management decisions affects the financial stability of an enterprise, its ability to develop prospectively and achieve financial success in the long term.

The enterprise management system includes a set of certain algorithms on formation of financial strategy and on organization and management of financial flows. Development of financial strategy in management accounting is a necessity for all business entities, which see their task in progressive development and maintaining a stable position in the market. 
The measures recommended in this research affect the financial flows of an agricultural enterprise in different directions, which allows to improve their value (optimize their value), continuity, sufficiency and synchronization.

Dynamic development of business environment forces the management of agricultural organizations to introduce separate tools, combinations of tools for budgeting, accounting and analysis, and in the future - and theoretically justified and practically proven technologies of management accounting. In a constantly developing organization there is a relationship of economic conditionality of these processes with the need to improve the efficiency of management systems by a rational combination of its functions.

\section{References}

1. J. Ukko, M. Nasiri, M. Saunila, T. Rantala. Journal of Cleaner Production, 236, 117626 (2019) doi.org/10.1016/j.jclepro.2019.117626

2. J. K. Staniškis, E. Katiliūtè. Journal of Cleaner Production, 236, 117542 (2019) doi.org/10.1016/j.jclepro.2019.07.017

3. G.S. Klychova, A.R. Zakirova, Z.R. Zakirov, G.R. Valieva. Asian Social Science, 1111, 308-312 (2015) DOI: 10.5539/ass.v11n11p308

4. P. Rikhardsson, O. Yigitbasioglu. International Journal of Accounting Information Systems, 29, 37-58, (2018) doi.org/10.1016/j.accinf.2018.03.001

5. J.-L. Combes, T. Kinda, R. Ouedraogo, P. Plane. Economic Modelling, 83, 195-209 (2019) doi.org/10.1016/j.econmod.2019.02.010

6. T. Sasaki. Pacific-Basin Finance Journal, 39, 1-15 (2016) doi.org/10.1016/j.pacfin.2016.05.002,

7. M. Obstfeld. Journal of International Money and Finance, 31, 469-480 (2012) doi.org/10.1016/j.jimonfin.2011.10.003

8. G.S. Klychova, M.M. Nizamutdinov, L.N. Safiullin, L.M. Mavlieva. Mediterranean Journal of Social Sciences, 5-18 (2014) DOI: 10.5901/mjss.2014.v5n18p215

9. G.S. Klychova, B.G. Ziganshin, A.R. Zakirova, G.R. Valieva, A.S. Klychova. Journal of Engineering and Applied Sciences, 12, 4958-4965 (2017) DOI: 10.3923/jeasci.2017.4958.4965

10. J.P. Fernandes. Land Use Policy, 82, 563-572 doi.org/10.1016/j.landusepol.2018.12.044

11. J. R. Kroes, A. S. Manikas. International Journal of Production Economics, 148, 37-50 (2014) doi.org/10.1016/j.ijpe.2013.11.008

12. A. Klychova, G. Klychova, A. Zakirova, R. Sungatullina, K. Mukhamedzyanov and E. Philippova. E3S Web of Conferences 110, $02072 \quad$ (2019) doi.org/10.1051/e3sconf/201911002072

13. A. V. Andreeva. Asian Social Science; 10-23, 102-112 (2014) doi:10.5539/ass.v10n23p102

14. O. Pavlatos, H. Kostakis. The Journal of Economic Asymmetries, 18, Article e00106 (2018) doi.org/10.1016/j.jeca.2018.e00106

15. Dz. Faizrakhmanov, A. Zakirova, G. Klychova, A. Yusupova and A. Klychova. E3S Web of Conferences 91, 06004 (2019) https://doi.org/10.1051/e3sconf/20199106004

16. G. Klychova, A. Zakirova, E. Sadrieva, F. Avkhadiev and A. Klychova E3S Web of Conferences. 91. 06002 (2019) doi.org/10.1051/e3sconf/20199106002 
17. M. Christersson, J. Vimpari, S. Junnila. Sustainable Cities and Society, 18, 66-73 (2015) doi.org/10.1016/j.scs.2015.06.002

18. F. C. Özbuğday, D. Fındık, K. M. Özcan, S. Başçı. Journal of Cleaner Production, 252, 119824 (2020) doi.org/10.1016/j.jclepro.2019.119824

19. G. Klychova, A. Zakirova, R. Mannapova, K. Pinina and Y. Ryazanova. E3S Web of Conferences 110, 02075 (2019) doi.org/10.1051/e3sconf/201911002075

20. K. Nolte, M. Ostermeier. World Development, 98, 430-446 (2017) doi.org/10.1016/j.worlddev.2017.05.012

21. X. Lu, Y. Li, Sh. Ke. Land Use Policy, 91, 104355 (2020) doi.org/10.1016/j.landusepol.2019.104355

22. A.-Y. Chang, Y.-T. Cheng. Journal of Cleaner Production, 207, 458-473, (2019) doi.org/10.1016/j.jclepro.2018.10.025

23. P. Lebedev. Procedia - Social and Behavioral Sciences, 213, 293-298 (2015) doi.org/10.1016/j.sbspro.2015.11.540

24. P. Antonetti, M. Anesa. Journal of Business Research, 74, 1-10 (2017) doi.org/10.1016/j.jbusres.2016.12.011

25. M. Arnold, M. Artz Accounting, Organizations and Society, 73, 50-67 (2019) doi.org/10.1016/j.aos.2018.06.001

26. M.N. Dudin, G. N. Kutsuri, I. J. Fedorova, S. S. Dzusova \& A. Z. Namitulina. Asian Social Science; 11-7; 290-296 (2015) doi:10.5539/ass.v11n7p290

27. J. W. Bull, N. Jobstvogt, A. Böhnke-Henrichs, A. Mascarenhas, R. Koss Ecosystem Services, Volume 17, 99-111 (2016)

28. Ch. Namugenyi, Sh. L Nimmagadda, T. Reiners. Procedia Computer Science, 159, 1145-1154 (2019) doi.org/10.1016/j.procs.2019.09.283 